\title{
EFFECT OF RESIDUAL ROCK PHOSPHATE AND BIOFERTILIZERS (RHIZOBIUM AND BIOPHOSPHATE) AND THEIR COMBINATIONS ON THE PRODUCTIVITY OF Stylosanthes guianensis CIAT 184
}

\author{
Johanna Lucia Amakali*, Djoko Soetrisno and Subur Priyono Sasmito Budhi \\ Faculty of Animal Science, Gadjah Mada University, Jl. Fauna No. 3, Bulaksumur, Yogyakarta, 55281
}

\begin{abstract}
The purpose of this research was to evaluate the agronomic effectiveness of rock phosphate, biological fertilizers (Rhizobium and bio-phosphate) and their combinations on dry matter (DM) production, nutrient content and in vitro dry matter digestibility (IVDMD) of Stylosanthes guianensis CIAT 184. This research was conducted at Forage and Pasture Laboratory, Universitas Gadjah Mada, Yogyakarta, Indonesia from February - October 2010. A strip plot design which consisted of two fertilizer factors with three (3) replicates was used. The first factor was the horizontal factor and consisted of four levels of biological fertilizers (Rhizobium and bio-phosphate) namely: $\mathrm{M}_{0}=$ control, $\mathrm{M}_{1}=$ Rhizobium $(0.5 \mathrm{~g} / \mathrm{plot}), \mathrm{M}_{2}=$ bio-phosphate $(0.6 \mathrm{~g} / \mathrm{plot})$ and $\mathrm{M}_{3}=$ combinations of Rhizobium and bio-phosphate. The second factor was the vertical factor and consisted of three levels of rock phosphate, namely: $\mathrm{P}_{0}=$ control, $\mathrm{P}_{1}=250 \mathrm{~kg} / \mathrm{ha}(32.5 \mathrm{P}$ $\mathrm{kg} / \mathrm{ha})$ and $\mathrm{P}_{2}=500 \mathrm{~kg} / \mathrm{ha}(65 \mathrm{P} \mathrm{kg} / \mathrm{ha})$. Defoliation was carried out every three months for 9 months. Results of the study showed that there was no significant difference in DM production $(\mathrm{kg} / \mathrm{ha})$ amongst treatments. Although the current research showed no significance difference amongs the treatments, DM production increased in the $2^{\text {nd }}$ harvest $(12.3 \%)$ and $4^{\text {th }}$ harvest $(7.1 \%)$ between $\mathrm{P}_{0}$ and $\mathrm{P}_{1}$. Combinations treatment $\mathrm{P}_{1} \mathrm{M}_{2}(21073.63 \mathrm{~kg} / \mathrm{ha})$ had the highest average DM production amongs treatments. Statistical analysis followed by Duncan's new Multiple Range Test (DMRT), showed that rock phosphate can significantly $(\mathrm{P}<0.05)$ increase fiber production of Stylosanthes guianensis. It showed that treatment $\mathrm{P}_{1}$ increased crude fiber production by $12.2 \%$ from $5864,47 \mathrm{~kg} / \mathrm{ha}$ to $6580,19 \mathrm{~kg} / \mathrm{ha}$. In addition, tests further revealed that there was a difference between $\mathrm{M}_{1}$ and $\mathrm{M}_{2}$, but had no effect on $\mathrm{M}_{0}$. There was no significant effect on production ( $\mathrm{kg} / \mathrm{ha}$ ) of crude protein, phosphorus, nitrogen free extract (NFE) and ash. In conclusion, treatments with rock phosphate and bio-fertilizers tend to increase productivity of Stylosanthes guianensis CIAT 184.
\end{abstract}

(Key words: Stylosanthes guianensis CIAT 184, Rock phosphate, Bio-phosphate, Rhizobium, and In vitro dry matter digestibility)

\section{Introduction}

The success of legumes is found in their ability to have a mutualistic symbioses with nitrogen $(\mathrm{N})$-fixing bacteria to directly capture atmospheric dinitrogen $\left(\mathrm{N}_{2}\right)$ to support plant growth (Hernandez et al., 2009). Nitrogen is commonly the most limiting plant nutrient in arable farming in the tropics and also the most expensive element as a mineral fertilizer, biological nitrogen fixation (BNF) therefore, holds great promise for smallholder farmers (Tripathi and Psychas, 1992).

However, although leguminous plants are expected to replenish soil nitrogen supplies, they are particularly hard hit by phosphorus $(\mathrm{P})$ deficiency because low supply inhibits effective nodulation and retards the biological nitrogen fixation process (Whiteman, 1980).

The nitrogen fixing systems require more phosphorus $(\mathrm{P})$ than non- $\mathrm{N}_{2}$ fixing systems, because the process consumes large amounts of energy, and energy-generating metabolism strongly depends upon the availability of P (Schulze et al., 2006).

\footnotetext{
*Korespondensi (corresponding author):

Telp. +264818792289

E-mail: oc_lesedi@yahoo.com
}

Phosphorous is one of important mineral for the plant. Manufactured water soluble phosphorus (WSP) fertilizers such as superphosphates are commonly recommended for correcting $\mathrm{P}$ deficiencies. The application of these inorganic fertilizers, results in low efficiency of WSP fertilizers such as triple superphosphate (TSP) or diammonium phosphate (DAP) by crops (Chien et al., 2010).

Another solution can be found in the direct application of rock phosphate which is an agronomic and economically sound alternative to the more expensive superphosphates in the tropics (Zapata and Roy, 2004). Phosphorus however, becomes unavailable to the plants after its application in soils; this is due to the formation of strong bonds between phosphorus with calcium and magnesium in alkaline $\mathrm{pH}$ and the same bonds with iron and aluminum in acidic soils (Mehrvars and Chaichi, 2008).

It is therefore, behind this background that this study aimed to investigate the use of biofertilizers (Biophosphate and Rhizobium), to increase the effectiveness of rock phosphate and thus the availability of P.

Stylosanthes guianensis CIAT 184 (stylo) is a legume that has been identified as a potential feed resource that could be used as a supplemental feed 
during periods of shortages. Another advantage of this legume is that as a $\mathrm{N}_{2}$-fixing plant, it has a higher capacity to utilize $\mathrm{P}$ from rock phosphate than nitrate-fed plants (Perez et al., 2007), because of their higher cation/anion uptake ratio and corresponding net release of $\mathrm{H}^{+}$.

This research is a continuation of the research conducted by Hutasoit (2010) who aimed at investigating the effect of rock phosphate and biological fertilizers on the production of Stylosanthes guianensis. The purpose of this research is to measure the agronomic effectiveness of rock phosphate, biofertilizers (biophosphate and Rhizobium) and their combinations on: the dry matter yield, nutrient compostion content and in vitro dry matter digestibility of Stylosanthes guianensis. This research would provide valuable information on the agronomic effectiveness of rock phosphate and provide an environmentally and economically attractive means to increase production.

\section{Materials and Methods}

\section{Description of the study area}

This research was conducted at Pasture and Forage Laboratory, Faculty of Animal Science, Universitas Gadjah Mada, Yogyakarta, Indonesia, for 9 months (February - October 2010). Average rainfall, temperature and humidity during this study was $240.4 \mathrm{~mm}, 32.1^{\circ} \mathrm{C}$ (maximum temp.) and $82.4 \%$ respectively (Adisutjipto Meteorology Stasion, 2010).

\section{Research materials}

This research used Stylosanthes guianensis CIAT 184 seeds, rock phosphate $\left(\mathrm{P}_{2} \mathrm{O}_{5} 13 \%\right)$, biophosphate (0.6 g/plot) and Rhizobium (0.5 $\mathrm{g} / \mathrm{plot}$ ) strain legume Cowpea (Vigna sinensis) with dosis of $1 \mathrm{~kg} / 150 \mathrm{~kg}$ seeds.

\section{Research method}

This research used the Strip Plot Design that consisted of two factors ( $3 \times 4$ factors). The first one being the horizontal factor, namely rock phosphate which consisted of three stages, namely: $\mathrm{P} 0=$ without rock phosphate

$\mathrm{P} 1$ = rock phosphate $250 \mathrm{~kg} / \mathrm{ha}(32.5 \mathrm{P} \mathrm{kg} / \mathrm{ha})$

$\mathrm{P} 2=$ rock phosphate $500 \mathrm{~kg} / \mathrm{ha}(65 \mathrm{P} \mathrm{kg} / \mathrm{ha})$

The second factor was the vertical factor namely, biological fertilizers rhizobium and biofosfat (M) which consist of four stages namely:

M0 = without biofertilizers

M1 = plus rhizobium
M2 = plus biophosphate

M3 = plus rhizobium dan biophosphate.

The current research did not apply any of the above-mentioned treatments during the course of the 9 month research period. Hence, was only applied once at the time of planting by Hutasoit (2010).

\section{Treatment combinations}

\begin{tabular}{|c|c|c|}
\hline $\begin{array}{l}\text { Plot } \\
\text { No. }\end{array}$ & Treatment & Treament kombination \\
\hline 1 & $\mathrm{P}_{0} \mathrm{M}_{0}$ & No treatment - control \\
\hline 2 & $\mathrm{P}_{0} \mathrm{M}_{1}$ & $\begin{array}{l}\text { Without rock phosphate + } \\
\text { Rhizobium }\end{array}$ \\
\hline 3 & $\mathrm{P}_{0} \mathrm{M}_{2}$ & $\begin{array}{l}\text { Without rock phosphate }+ \\
\text { biophosphate }\end{array}$ \\
\hline 4 & $\mathrm{P}_{0} \mathrm{M}_{3}$ & $\begin{array}{l}\text { Without rock phosphate }+ \\
\text { Rhizobium + biophosphate }\end{array}$ \\
\hline 5 & $\mathrm{P}_{1} \mathrm{M}_{0}$ & $\begin{array}{l}\text { rock phosphate } 250 \mathrm{~kg} / \mathrm{ha}+\mathrm{no} \\
\text { biofertilizers }\end{array}$ \\
\hline 6 & $\mathrm{P}_{1} \mathrm{M}_{1}$ & $\begin{array}{l}\text { rock phosphate } 250 \mathrm{~kg} / \mathrm{ha}+ \\
\text { Rhizobium }\end{array}$ \\
\hline 7 & $\mathrm{P}_{1} \mathrm{M}_{2}$ & $\begin{array}{l}\text { rock phosphate } 250 \mathrm{~kg} / \mathrm{ha}+ \\
\text { biophosphate }\end{array}$ \\
\hline 8 & $\mathrm{P}_{1} \mathrm{M}_{3}$ & $\begin{array}{l}\text { rock phosphate } 250 \mathrm{~kg} / \mathrm{ha}+ \\
\text { Rhizobium + biophosphate }\end{array}$ \\
\hline 9 & $\mathrm{P}_{2} \mathrm{M}_{0}$ & $\begin{array}{l}\text { rock phosphate } 500 \mathrm{~kg} / \mathrm{ha}+\text { no } \\
\text { biofertilizers }\end{array}$ \\
\hline 10 & $\mathrm{P}_{2} \mathrm{M}_{1}$ & $\begin{array}{l}\text { rock phosphate } 500 \mathrm{~kg} / \mathrm{ha}+ \\
\text { Rhizobium }\end{array}$ \\
\hline 11 & $\mathrm{P}_{2} \mathrm{M}_{2}$ & $\begin{array}{l}\text { rock phosphate } 500 \mathrm{~kg} / \mathrm{ha}+ \\
\text { biophosphate }\end{array}$ \\
\hline 12 & $\mathrm{P}_{2} \mathrm{M}_{3}$ & $\begin{array}{l}\text { rock phosphate } 500 \mathrm{~kg} / \mathrm{ha}+ \\
\text { Rhizobium }+ \text { biophosphate }\end{array}$ \\
\hline
\end{tabular}

\section{Variables measured}

The following were variables observed: dry matter (DM) content, crude protein (CP), crude fiber (CF), content (AOAC, 2005), phosphorus concentration, soil analysis and in vitro dry matter digestibility (IVDMD) (Tilley and Terry, 1963). Data of the proximate analysis and $\mathrm{P}$ concentration were used to calculate the production per hectare. Dry matter production was calculated by multiplying the dry matter content by the fresh weight, while the other variables were calculated based on the DM production.

\section{Statistical analysis}

Data were analyzed statistically using SPSS for windows version 16 and followed by Duncan's new Multiple Range Test (DMRT) when there was a significant effect. 


\section{Results and Discussion}

\section{Soil analysis of research area}

The total $\mathrm{Ca}$ also reduced from $0.54 \%$ to $0.02 \%$, this coincides with the reduced $\mathrm{pH}$ level (from 6.9 to 6.7), because as $\mathrm{Ca}$ level drops, the more acidic soils become. In addition, as a legume, stylo has high demand for Ca (Zapata and Roy, 2004). The available cation exchange capacity (CEC) recorded was 22.37, this value lies within the normal range 15 - 40, and Kettering et al. (2007) reported that at these levels soils are more clay or more organic matter is present with high water holding capacity. Camberato (2001) further reported that $\mathrm{pH} 6.5$ provides a near optimum CEC levels and $\mathrm{P}$ availability.

\section{Dry matter (DM) content and production}

Results showed that the $2^{\text {nd }}$ harvest recorded an average DM content of $25.79 \%$ based on the interaction effect, and ranged between 24.90 (rock phosphate $250 \mathrm{~kg} / \mathrm{ha}+$ Rhizobium) - 26.70\% (rock phosphate $250 \mathrm{~kg} / \mathrm{ha}+$ biophosphate); the $3^{\text {rd }}$ harvest recorded an average DM of $30.19 \%$, and ranged between 28.70-32.60\% (without rock phosphate + Rhizobium) and finally the $4^{\text {th }}$ harvest recorded an average DM (\%) of $26.74 \%$ and ranged between 24.70 (rock phosphate $250 \mathrm{~kg} / \mathrm{ha}+$ no biofertilizers) - $28.70 \%$ (rock phosphate $250 \mathrm{~kg} / \mathrm{ha}$ + Rhizobium). The $1^{\text {st }}$ harvest recorded (Hutasoit, 2010) an average of $23.54 \%$ and ranged between 22.20 (rock phosphate $250 \mathrm{~kg} / \mathrm{ha}+$ Rhizobium) $25.20 \%$ (rock phosphate $250 \mathrm{~kg} / \mathrm{ha}+$ biophosphate). The $3^{\text {rd }}$ harvest recorded the highest DM content, but had the lowest DM (kg/ha) production.

Results in Table 1 show that treatments had no significant effect on the DM production $(\mathrm{kg} / \mathrm{ha})$ of stylo.

Although no statistically significance difference, amongs treatments were found production increased in the $2^{\text {nd }}$ harvest $12.3 \%$ and $4^{\text {th }}$ harvest $7.1 \%$ between $\left(\mathrm{P}_{0}\right)$ and $\left(\mathrm{P}_{1}\right)$. Combinations treatment rock phosphate $250 \mathrm{~kg} / \mathrm{ha}+$ biophosphate $(21073.63 \mathrm{~kg} / \mathrm{ha})$ had the highest average DM production amongst treatments.

Temperature probably had one of the greatest effects on the low DM average. If soil temperatures

Table 1. Effect of rock phosphate, bio-fertilizers and their interactions on DM production $(\mathrm{kg} / \mathrm{ha})$ of stylo

\begin{tabular}{|c|c|c|c|c|}
\hline \multirow{2}{*}{ Treatment } & \multicolumn{4}{|c|}{ Average DM production $(\mathrm{kg} / \mathrm{ha})$} \\
\hline & Harvest 2 & Harvest 3 & Harvest 4 & Average \\
\hline \multicolumn{5}{|l|}{ Rock phosphate } \\
\hline $\mathrm{P} 0$ & 21624.06 & 15466.08 & 18437.34 & 18509.16 \\
\hline $\mathrm{P} 1$ & 24291.36 & 14978.51 & 19746.00 & 19671.96 \\
\hline $\mathrm{P} 2$ & 21097.70 & 14685.70 & 19626.65 & 18470.02 \\
\hline \multicolumn{5}{|l|}{ Bio-fertilizers } \\
\hline M0 & 22146.76 & 15466.08 & 20167.95 & 19260.26 \\
\hline M1 & 20902.49 & 13256.86 & 19428.88 & 17862.74 \\
\hline M2 & 24173.44 & 15217.72 & 18995.48 & 19462.21 \\
\hline M3 & 22128.27 & 13679.24 & 18487.68 & 18098.40 \\
\hline \multicolumn{5}{|c|}{ Combination treatment of rock phosphate and bio-fertilizers } \\
\hline P0M0 & 20668.77 & 12798.73 & 19231.81 & 17566.44 \\
\hline P0M1 & 23421.31 & 12530.47 & 18248.91 & 18066.90 \\
\hline P0M2 & 20428.34 & 14661.62 & 17252.68 & 17447.55 \\
\hline P0M3 & 21977.82 & 14212.04 & 19015.96 & 18401.94 \\
\hline $\mathrm{P} 1 \mathrm{M} 0$ & 23774.10 & 17834.55 & 20293.99 & 20634.21 \\
\hline P1M1 & 23201.76 & 12724.86 & 19917.57 & 18614.73 \\
\hline $\mathrm{P} 1 \mathrm{M} 2$ & 27343.98 & 15427.32 & 20449.60 & 21073.63 \\
\hline P1M3 & 22845.61 & 13927.32 & 18322.85 & 18365.26 \\
\hline $\mathrm{P} 2 \mathrm{M} 0$ & 21997.41 & 15764.96 & 20978.04 & 19580.14 \\
\hline P2M1 & 16084.39 & 14515.25 & 20120.17 & 16906.60 \\
\hline $\mathrm{P} 2 \mathrm{M} 2$ & 24747.99 & 15564.21 & 19284.17 & 19865.46 \\
\hline P2M3 & 21561.00 & 12898.36 & 18124.23 & 17527.86 \\
\hline Average & 22337.71 & 14404.97 & 19270.00 & 18670.89 \\
\hline
\end{tabular}


are high, dry matter can be lost through excessive respiration. Another reason may be due the excess defoliation in the first year (4 times), as according to Tripathi and Psychas (1992) defoliation decreases the photosynthetic ability of legumes and impairs $\mathrm{N}_{2}$ fixation which can lead to nodule decay. Results also showed that increased levels of rock phosphate $\left(\mathrm{P}_{2}\right) 500 \mathrm{~kg} / \mathrm{ha}(65 \mathrm{P} \mathrm{kg} / \mathrm{ha})$ did not increase yield, with treatment $\left(\mathrm{P}_{2}\right) 18470.02 \mathrm{~kg} / \mathrm{ha}$ having a lower yield as compared to the control. Similarly in their study to test different levels of fertilizer (P) application ranging between $0,20,40-320 \mathrm{~kg}$ $\mathrm{P} / \mathrm{ha}$, Crespo and Curbelo (1990) found that increased levels more than $23.3 \mathrm{~kg} \mathrm{P} / \mathrm{ha}$ did not increase yields.

Increased production in the $2^{\text {nd }}$ harvest may be because during the growing period dissolved $\mathrm{P}$ could have moved through the soil to the roots (Bushman et al., 2009) and was absorbed by stylo and hence increased growth. In addition, the characteristic of stylo's response to phosphatic fertilization can double its production t' Mannetje (1992). In addition, Mckenzie and Middleton (1997) stated that a good supply of $\mathrm{P}$ has been associated with increased root growth, which means the plants, can explore more soil for nutrients and moisture.

There was a trend between rainfall and DM production $(\mathrm{kg} / \mathrm{ha})$, this statement is supported by Bushman et al. (2009) who reported that the activity of microorganisms is highly influenced by soil temperature and soil moisture.

\section{Crude protein (CP) content and production}

The CP represents a composite analysis of 3 harvests (harvest 2 - 4) collected over a 9 month period. Treatment with rock phosphate had no effect on the CP content of stylo recording $17.67 \%\left(\mathrm{P}_{1}\right)$ and $17.84 \%\left(\mathrm{P}_{2}\right)$ as compared to the control 17.96 $\%\left(\mathrm{P}_{0}\right)$. Treatment with bio-fertilizers also had no effect on $\mathrm{CP}$ content, with the control $\left(\mathrm{P}_{0}\right)$ recording the highest CP content at $18.08 \%$.

The total average CP content based on the interaction effects recorded $17.82 \%$, and varied between $17.23 \%\left(\mathrm{P}_{1} \mathrm{M}_{3}\right)-18.60 \%\left(\mathrm{P}_{0} \mathrm{M}_{0}\right)$. D'Mello and Devendra (1995) reported CP figures ranged from 12.1 to $18.1 \%$ for the whole plant, this record

Table 2. Effect of rock phosphate, bio-fertilizers and their interactions on CP content of stylo

\begin{tabular}{ccccc}
\hline \multirow{2}{*}{ Treatment } & \multicolumn{3}{c}{ Average CP content (\%) } \\
\cline { 2 - 5 } & Rep 1 & Rep 2 & Rep 3 & Average \\
\hline Rock phosphate & & & 18.29 & 17.96 \\
P0 & 17.51 & 18.08 & 17.22 & 17.67 \\
P1 & 17.21 & 18.60 & 17.86 & 17.84 \\
P2 & 17.43 & 18.23 & & \\
Bio-fertilizers & & & 17.97 & 18.08 \\
M0 & 18.09 & 18.18 & 18.02 & 17.69 \\
M1 & 16.74 & 18.32 & 17.46 & 17.90 \\
M2 & 17.87 & 18.38 & 17.7 & 17.62 \\
M3 & 16.84 & 18.31 & & 18.60 \\
Combination treatment & of rock phosphate and bio-fertilizers & & 17.93 \\
P0M0 & 19.63 & 17.05 & 19.11 & 17.68 \\
P0M1 & 17.18 & 17.96 & 18.66 & 17.62 \\
P0M2 & 17.24 & 18.29 & 17.52 & 18.25 \\
P0M3 & 16.00 & 19.00 & 17.85 & 17.43 \\
P1M0 & 17.63 & 19.77 & 17.34 & 17.79 \\
P1M1 & 16.85 & 18.63 & 16.81 & 17.23 \\
P1M2 & 17.12 & 18.77 & 17.49 & 17.39 \\
P1M3 & 17.25 & 17.21 & 17.22 & 17.71 \\
P2M0 & 17.00 & 17.73 & 17.45 & 18.24 \\
P2M1 & 16.18 & 18.36 & 18.58 & 17.82 \\
P2M2 & 19.25 & 18.09 & 17.38 & \\
P2M3 & 17.27 & 18.72 & 18.03 & 17.79 \\
Average & 17.38 & 18.3 & & \\
\hline
\end{tabular}


is slightly lower than the CP recorded in this study, which had an average of $17.82 \%$ for the whole plant.

The total average production of CP recorded $3318.91 \mathrm{~kg} / \mathrm{ha}$ and ranged between $3001.93\left(\mathrm{P}_{2} \mathrm{M}_{1}\right)$ $-3745.41 \mathrm{~kg} / \mathrm{ha}\left(\mathrm{P}_{1} \mathrm{M}_{0}\right)$ as shown in Table 2 .

There was no significant effect amongst the different rock phosphate levels. Bio-fertilizers also had no significant effect on production. The biological fixation of nitrogen may have been affected at earlier stages of plant growth due to the harsh environmental conditions experienced at the initial stage of growth. Zahran (1999) reported that a decrease in the infectivity of cowpea rhizobia was found at $35^{\circ} \mathrm{C}$. Serraj and Adu-Gyamti (2004) report that it is well documented that both low and high extremes temperature can prevent nodulation, or if nodulation occurs, can inhibit nitrogen fixation. Nodule functioning in common beans (Phaseolus spp.) is optimal between 25 and $30^{\circ} \mathrm{C}$ and is hampered by root temperatures between 30 and $33^{\circ} \mathrm{C}$ (Zahran, 1999). During the research, temperatures recorded an average of $32.1^{\circ} \mathrm{C}$; this could have been one of the factors that affected the microbial activity and hampered nodulation.

Sensitivity of symbiotic nitrogen fixation to phosphorus deficiency could have affected the CP production; if bio-phosphate microbes were rendered dormant due to the above mentioned conditions, P-deficiency would drastically cause a reduction in nodulation (Hernandez et al., 2009) and nitrogenase activity.

\section{Crude fiber content and production}

The total average CF (\%) based on the interaction effects recorded $33.01 \%$ and ranged between $31.78\left(\mathrm{P}_{0} \mathrm{M}_{1}\right)-34.11 \%\left(\mathrm{P}_{1} \mathrm{M}_{1}\right)$. Treatment with $\mathrm{P}_{1}(250 \mathrm{~kg} / \mathrm{ha})$ had the highest effect on $\mathrm{CF}$ content recorded $33.41 \%$. Keoboualapheth and Mikled (2003) recorded CF of stylo was 30\%, which is lower than results in current studies. Keopaseuth et al. (2004) recorded even lower CF at $17.3 \%$. The apparent increasing may be due to the aging of stylo, as sub-samples were collected for a one year period. Maturity through its effects on plant composition is recognized as a major

Table 3. Effect of rock phosphate, bio-fertilizers and their interactions on CF contents of stylo

\begin{tabular}{ccccc}
\hline \multirow{2}{*}{ Treatment } & \multicolumn{3}{c}{ Average CF content (\%) } \\
\cline { 2 - 5 } Rock phosphate & Rep 1 & Rep 2 & Rep 3 & Average \\
P0 & 33.66 & 32.05 & 32.49 & 32.73 \\
P1 & 33.85 & 32.71 & 33.67 & 33.41 \\
P2 & 34.87 & 30.61 & 33.22 & 32.90 \\
Bio-fertilizers & & & \\
M0 & 34.45 & 31.68 & 33.43 & 33.19 \\
M1 & 33.97 & 33.32 & 31.94 & 33.08 \\
M2 & 33.87 & 31.51 & 33.57 & 32.98 \\
M3 & 34.21 & 30.65 & 33.57 & 32.81 \\
Combination treatment & of rock phosphate and bio-fertilizers & & \\
P0M0 & 33.31 & 34.4 & 32.40 & 33.37 \\
P0M1 & 32.59 & 32.3 & 30.45 & 33.78 \\
P0M2 & 35.05 & 32.45 & 33.20 & 32.20 \\
P0M3 & 33.67 & 29.03 & 33.90 & 34.04 \\
P1M0 & 36.36 & 31.70 & 34.05 & 34.11 \\
P1M1 & 33.24 & 35.28 & 33.82 & 32.20 \\
P1M2 & 33.00 & 29.98 & 33.62 & 33.29 \\
P1M3 & 32.80 & 33.89 & 33.18 & 32.14 \\
P2M0 & 33.67 & 28.93 & 33.83 & 33.33 \\
P2M1 & 36.08 & 32.38 & 31.54 & 33.94 \\
P2M2 & 33.56 & 32.10 & 33.89 & \\
P2M3 & 36.17 & 29.03 & 33.62 & 33.13 \\
Average & 34.13 & 31.79 & & \\
\hline
\end{tabular}


determinant of forage quality (Onyeonagu et al., 2012). Because, as plant matures the cell wall content increases and cell content decreases.

Table 3 shows that the total $\mathrm{CF}$ average production $(\mathrm{kg} / \mathrm{ha})$ recorded $6186.74 \mathrm{~kg} / \mathrm{ha}$ and ranged between $5616.40 \mathrm{~kg} / \mathrm{ha}\left(\mathrm{P}_{2} \mathrm{M}_{1}\right)-7069.30$ $\left(\mathrm{P}_{1} \mathrm{M}_{0}\right)$. The highest $\mathrm{CF}$ was recorded in combination treatment $\left(\mathrm{P}_{1} \mathrm{M}_{0}\right) 7069.30 \mathrm{~kg} / \mathrm{ha}$, similarly Hutasoit (2010) also recorded combination $\left(\mathrm{P}_{1} \mathrm{M}_{0}\right)$ as the treatment with the highest $\mathrm{CF}$ content. SPSS statistical analysis followed by DMRT showed that there was a significant effect $(\mathrm{P}<0.05)$ of rock phosphate application on $\mathrm{CF}$ production, and there was a significant difference between $\left(\mathrm{P}_{0}\right)$ and $\left(\mathrm{P}_{1}\right)$. It showed that treatment $\mathrm{P}_{1}$ increased crude fiber production by $12.2 \%$ from 5864.47 $\mathrm{kg} / \mathrm{ha}$ to $6580.19 \mathrm{~kg} / \mathrm{ha}$. The results also showed a significant difference between $\left(\mathrm{M}_{1}\right)$ and $\left(\mathrm{M}_{2}\right)$ on $\mathrm{CF}$ production (kg/ha).

\section{Phosphorus content and production}

Treatment $\mathrm{P}_{2}$ had the highest effect on phosphorus concentration, and $\mathrm{M}_{2}$ had highest concentration $0.42 \%$ amongst the bio-fertilizer treatments, as compared to the control $\left(\mathrm{M}_{0}\right) 0.38 \%$. The total average $\mathrm{P}$ based on the interaction effects recorded $0.40 \%$ and ranged between $0.35 \%\left(\mathrm{P}_{1} \mathrm{M}_{3}\right)$ $-0.50 \%\left(\mathrm{P}_{2} \mathrm{M}_{3}\right)$. Compared to Hutasoit (2010) who recorded an average $\mathrm{P}$ of $0.13 \%$ and ranged between $0.12 \%\left(\mathrm{P}_{2} \mathrm{M}_{2}\right)-0.16 \%\left(\mathrm{P}_{2} \mathrm{M}_{0}\right)$.

The highest $\mathrm{P}$ content $0.50 \%\left(\mathrm{P}_{2} \mathrm{M}_{3}\right)$ showed that combinations of rock phosphate levels at 500 $\mathrm{kg} / \mathrm{ha}(65 \mathrm{P} \mathrm{kg} / \mathrm{ha})$ and bio-fertilizers combinations (bio-phosphate and Rhizobium) had an increasing effect on $\mathrm{P}$ content.

Crespo and Curbelo (1990) in their research to determine the response of Stylosanthes guianensis CIAT-184 to phosphoric fertilization, recorded critical minimum $\mathrm{P}$ concentration in the plantamounted to $0.16 \%$, while $\mathrm{P}$ phytotoxicity symptoms were present when $320 \mathrm{~kg} \mathrm{P} / \mathrm{ha}$ was applied and a $\mathrm{P}$ content of $0.71 \%$ was attained. Furthermore, they reported that increased application of fertilizer increased $\mathrm{P}$ concentration in plant. Similarly, Underwood and Suttle (1999) reported that phosphate application increases herbage phosphorus concentrations.

The phosphorus production $(\mathrm{kg} / \mathrm{ha})$ of stylo as per treatment with rock phosphate, biological fertilizers and their interaction effect recorded an average $\mathrm{P}(\mathrm{kg} / \mathrm{ha}) 75.51$ and ranged between 61.43 $\left(\mathrm{P}_{1} \mathrm{M}_{3}\right)-89.77 \% \quad\left(\mathrm{P}_{2} \mathrm{M}_{3}\right)$. Statistical analysis

Table 4. Effect of rock phosphate, bio-fertilizers and their interactions on in vitro dry matter digestibility of stylo

\begin{tabular}{ccccc}
\hline \hline \multirow{2}{*}{ Treatment } & \multicolumn{4}{c}{ Average in vitro dry matter digestibility (\%) } \\
\cline { 2 - 5 } Rock phosphate & Rep 1 & Rep 3 & Average \\
P0 & 50.11 & 49.19 & 47.81 & 49.04 \\
P1 & 48.99 & 50.13 & 46.79 & 48.64 \\
P2 & 51.05 & 48.17 & 50.11 & 49.78 \\
Bio-fertilizers & & & & \\
M0 & 51.14 & 49.08 & 49.17 & 49.80 \\
M1 & 50.06 & 48.83 & 48.30 & 49.06 \\
M2 & 49.30 & 48.79 & 47.72 & 48.60 \\
M3 & 49.71 & 49.98 & 47.74 & 49.14 \\
Combination treatment of rock phosphate and bio-fertilizer & & 49.86 \\
P0M0 & 49.99 & 51.38 & 48.21 & 48.36 \\
P0M1 & 49.10 & 48.57 & 47.40 & 49.61 \\
P0M2 & 53.68 & 49.26 & 45.90 & 48.31 \\
P0M3 & 47.68 & 47.55 & 49.71 & 48.65 \\
P1M0 & 50.01 & 48.52 & 47.41 & 49.34 \\
P1M1 & 49.61 & 50.01 & 48.41 & 49.33 \\
P1M2 & 46.24 & 47.38 & 48.36 & 50.89 \\
P1M3 & 50.11 & 54.68 & 42.98 & 49.48 \\
P2M0 & 53.42 & 47.35 & 51.90 & 48.87 \\
P2M1 & 51.46 & 47.90 & 49.09 & 49.86 \\
P2M2 & 47.97 & 49.74 & 48.90 & 49.15 \\
P2M3 & 51.35 & 47.70 & 50.53 & \\
Average & 50.05 & 49.17 & 48.23 & \\
\hline
\end{tabular}


showed that interaction treatment with rock phosphate and bio-fertilizers had no significant effect on P production $(\mathrm{kg} / \mathrm{ha})$ of stylo.

\section{In vitro dry matter digestibility (IVDMD)}

In this experiment, IVDMD averaged $49.15 \%$ and ranged between $47.33 \%\left(\mathrm{P}_{1} \mathrm{M}_{2}\right)$ to $50.89 \%$ $\left(\mathrm{P}_{2} \mathrm{M}_{0}\right)$. Treatments with rock phosphate, biofertilizers and their interactions had no significant effect on in vitro digestibilities. Table 4 shows the digestibilities as affected by treatments.

Cook et al. (2005) reported IVDMD of stylo range between 52-60\%. Valarini and Possenti (2006) had similar IVDMD of stylo at $57.0 \%$. Phonepaseuth and Ledin (2003) recorded digestibility of stylo between $60-70 \%$. They further reported that increased age and lignifications may reduce digestibility to below $40 \%$.

The low digestibility was a direct effect of the increased fiber content. This increase in fiber content influenced the digestibility of stylo, because a fiber fraction of a feed is closely related to its digestibility (McDonald et al., 1995).

Buxton and Redfearn (1997) reported that the major factor lowering digestibilites of forages as they mature is the higher fiber and lower cellsoluble concentrations of mature forages. In addition, lignin is also primarily responsible for limiting digestibility of fiber, as lignin interferes with microbial degradation of fiber polysaccharides by acting as a physical barrier. Legume stems have a ring of thick-walled, lignified cells resistant to digestion.

\section{Conclusion and Recommendation}

\section{Conclusion}

Results of the study showed that residual rock phosphate and bio-fertilizers application tended to increase re-growth productivity of Stylosanthes guianensis CIAT 184. The most effective interaction between treatments was $\left(\mathrm{P}_{1}\right) 250 \mathrm{~kg} / \mathrm{ha}$ (32.5 P Kg/ha) and $\left(\mathrm{M}_{2}\right)$ (bio-phosphate). Harvest 3 showed that $\left(\mathrm{P}_{1}\right)$ and $\left(\mathrm{P}_{2}\right)$ had lower yields as compared to $\mathrm{P}_{0}$. Rock phosphate significantly increased fiber production of stylo by $12.2 \%$, while bio-fertilizers seemed not to influence the fiber production in statistical analysis. In vitro dry matter digestibility was not significantly affected by interaction treatment of rock phosphate, biophosphate and Rhizobium. Average P concentration increased from $0.13 \%$ (harvest 1 ) $-0.40 \%$ (in current research).

\section{Recommendation}

Further analysis on the chemical composition, mineralogy and its influence on the reactivity of rock phosphate can further be researched. Also, a detailed economic analysis including cost of production can be formulated to compare the cost of rock phosphate to that of watersoluble-phosphate fertilizer. The neutral detergent fiber (NDF) and acid detergent fiber (ADF) using the Van Soest fiber fractionation system can be analyzed, as this estimates the structural carbohydrates and evaluates the usable area of the plant cell wall.

\section{References}

Adisutjipto Meteorology Stasion. 2010. Climatology data. Tentara Nasional Indonesia. Airforce. Meteorology Department, Adisutjipto Airport, Yogyakarta.

AOAC. 2005. Method of Analysis. $18^{\text {th }}$ ed. Association of Official Analytical Chemists. PO Box 504, Benjamin Franklin Station, Washington DC.

Bushman, L., J. Lamb, G. Randall, G. Rehm and M. Schmitt. 2009. The nature of phosphorus in soils. Phosphorus in agriculture environment. University of Minnesota. Minnesota.

Buxton, D. R. and D. D. Redfearn. 1997. Plant limitations to fiber digestion and utilization. USDA-ARS-FCR, Department of Agronomy, Iowa State University, IA 50011 and U.S. Dairy Forage Research Center, Madison. J. Nutr. 127: 814-818.

Camberato, J. J. 2001. Cation Exchange Capacity Everything you want to know and more. Crop and Soil Environmental Science, Clemson University, South Carolina.

Chien, S. H. N., L. I. Prochnow and R. Mikkelson. 2010. Agronomic use of phosphate rock for direct application. Better Crops 94.

Cook, B. G., Pengelly, B. C. Brown, S. D. Donnelly, J. L. Eagles, D. A. Franco, M. A. Hanson, J. Mullen, B. F. Partridge, I. J. Peters, M. and R. Schultze-Kraft. 2005. Tropical Forages: an interactive selection tool., [CD-ROM], CSIRO, DPI\&F (Qld), CIAT and ILRI, Brisbane.

Crespo, G. and F. Curbelo. 1990. Response of Stylosanthes guianensis CIAT-184 to phosphoric fertilization in a luvisol Pinar del Rio province. Cuban Journal of Agricultural Science 24: 131-137.

D'Mello, J. P. F. and C. Devendra. 1995. Tropical Legumes in Animal Nutrition, CAB International, Wallingford. 
Hernandez, G., O. Valdez-Lopez, M. Ramirez, N. Goffard, G. Weiller, R. Aparicio-Fabre, S. I. Fuentes, A. Erban, J. Kopka, M. K. Udvardi and C. P. Vance. 2009. Global Changes in thr Transcript and Metabolic Profiles during Symbiotic Nitrogen Fixation in PhosphorusStressed Common Bean Plants. Plant Physiology 151: 1221-1238.

Hutasoit, R. 2010. Pengaruh pemberian rock phosphate dan pupuk hayati terhadap produksi and kualitas Stylosanthes guianensis CIAT 184. Universitas Gadjah Mada, Yogyakarta.

Keoboualapheth, C. and C. Mikled. 2003. Livestock Research Centre, National Agriculture and Forestry Research Institute, Ministry of Agriculture and Forestry, Lao PDR. Department of Animal Science, Faculty of Agriculture, Chian Mai University, Chiang Mai.

Keopaseuht, T., T. Y. Chhay, B. Bounthong and T. R. Preston. 2004. Effect of Methods of Offering Foliages of Gliricida sepium and Stylosanthes guianensis CIAT 184 (stylo) to Goats on Intake and Digestibility. Livestock Research Center, Namxuang, Lao PDR.

Kettering, Q., S. Reid and R. Rao. 2007. Cation Exchange Capacity (CEC). Department of Crop and Soil Science, Cornell University Cooperative Extension, Ithaca, New York.

McDonald, P., R. A. Edwards and J. F. D. Greenhalgh. 1995. Animal Nutrition, $5^{\text {th }}$ ed. Longman House, Burnt Mill, Harlow, Essex CM20 2JE, London.

McKenzie, R. H. and A. Middleton. 1997. Phosphorus Fertilizer Applications in Crop Production. Agronomy Unit. Alberta Agriculture and Rural Development. Lethbrige. Visited 12 July, 2012.

Phonepaseuth, P. and I. Ledin. 2003. Effect of stylo 184 (Stylosanthes guianensis), Gamba Grass (Andropogan gayanus cv. Kent) in Diets for Growing Goats. Livestock Research for Rural Development, 15 Lao, PDR. Available at P.phengsavanh@cgair.org.com. Accession date: July 10, 2012.

Perez, M. J., T. J. Smyth and D. W. Israel. 2007. Comparative effects of two forage species on rhizosphere acidification and solubilization of phosphate rocks of different reactivity. J. Plant Nutr. 30: 1421-1439.
Onyeonagu, C. C., O. A. Anyadiegwu and T. K. Uwalaka. 2012. The quality of crop fractions of a degraded Panicum maximum pasture under different cutting intervals and nitrogen fertilizer rates. Afr. J. Agric. Res. 7: 21742182.

Serraj, R. and J. A. Adu-Gyamti. 2004. Role of symbiotic nitrogen fixation in the improvement of legume productivity under stressed environment. West African Journal of Applied Ecology 6.

Schulze, J., G. Temple, S. J. Temple, H. Beschow and C. P. Vance. 2006. Nitrogen Fixation by White Lupin under Phosphorus Deficiency. Annals of Botany 98: 731-740.

Tilley, J. M., and R. A. Terry. 1963. A two-stage technique for the in-vitro digestion of forage crops. J. Br. Grassl. Soc. 18: 104-111.

Tripathi, B. R. and P. J. Psychas. 1992. The Afneta Alley Farming Training Manual. Volume 2. Source Book for Alley Farming Research. Alley Farming Network for Tropical Africa, Internationl Institute of Tropical Agriculture, Ibadan.

t' Mannetje, L. 1992. Stylosanthes guianensis (Aublet) swartz. In: Plant Resources of South-East Asia No 4. Forages. t' Mannetje L. and R. M. Jones (eds.). Pudoc-DLO, Wageningen. Pp. 211-213.

Underwood, E. J. and N. F. Suttle. 1999. The Mineral Nutrition of Livestock, 3rd Edition, CAB international, Wallington, UK.

Valarini, M. J. and R. A. Possenti. 2006. Research note: Nutritive value of a range of tropical forage legumes. Tropical Grasslands 40: 183187.

Whiteman, P. C. 1980. Tropical Pasture Science. Oxford university press. New York.

Zahran, H. H. 1999. Rhizobium - Legume symbiosis and nitrogen fixation under severe conditons and in an arid cimate. Journal of American Society for Microbiology 63: 968989.

Zapata, F. and R. N. Roy. 2004. Use of phosphate rock for sustainable agriculture. Food and Agriculture Organization, Land and Water Development Division, 00100 Rome. 